\title{
Communication channels in the host community market adopted by Chinese immigrant entrepreneurs
}

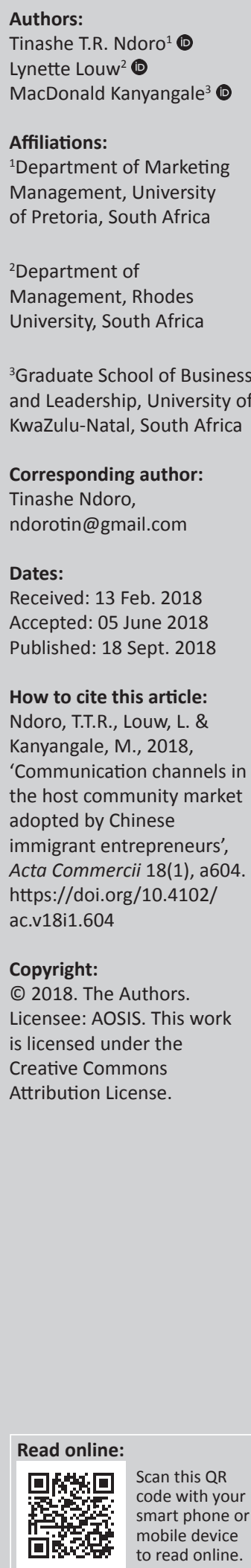

Orientation: There is a growing prevalence of entrepreneurial activity by immigrant entrepreneurs in different sectors of various economies across the world. Immigrant entrepreneurs seek to identify opportunities to grow and sustain their businesses in hostile business markets. Immigrant entrepreneurs use an array of channels of communication to gain insight of the opportunities in the market.

Research purpose: The study sought to investigate the communication channels used by Chinese immigrant entrepreneurs to identify opportunities in the host community market.

Motivation for the study: The study was undertaken given the dearth of research on the role of communication channels in enabling the identification of opportunities by immigrant entrepreneurs.

Research design, approach and method: A qualitative research design was adopted in which purposive and snowball sampling were adopted. Semi-structured interviews were conducted with 21 Chinese immigrant entrepreneurs operating small businesses in the South African context.

Main findings: The results indicate that the immigrant entrepreneurs identified opportunities in the business environment through establishing channels of communication that manifested as networks with family members, customers, local employees and competitors. Building relationships through networks was key for the process of identifying opportunities.

Practical/managerial implications: The study provides evidence that information about opportunities in the market is identified through dynamic channels of communication characterised by networks with different stakeholders.

Contribution/value-add: Communication channels are pivotal in enabling the identification of opportunities in the business environment. Immigrant entrepreneurs actively create and sustain their relationships with various stakeholders in the business environment to be able to identify opportunities in the business environment.

\section{Introduction}

Immigrant-owned businesses are increasingly becoming key contributors to the overall economic and social development of host countries through fostering job creation, entrepreneurial activity and poverty alleviation (Fatoki \& Oni 2014; Sahin, Nijikamp \& Baycan-Levent 2006). Although limited information is available on the business practices of immigrant entrepreneurs, there is a growing acknowledgement of their importance to the growth and development of global economies (Wadhwa et al. 2007).

Sahin et al. (2006:1) argue that 'studies on immigrant entrepreneurship in both the USA and Europe have recognised the significant share of immigrants in small business activities'. These studies focus on various management practices such as teamwork, resource mobilisation and communication. Several scholars (Chrysostome 2010; Halkias et al. 2007; Sahin et al. 2006; Wadhwa et al. 2007) suggest that entrepreneurship by immigrants has a direct positive impact on the host economies. Moreover, Halkias et al. (2007) add that immigrant-founded companies contribute positively to the levels of employment in the host country. However, despite the prevalence of such literature at an international level, not much is known about the contribution and management of immigrant-owned small businesses in South Africa.

In the South African context, several scholars (Fatoki \& Oni 2014; Khosa \& Kalitanyi 2014; Masocha, Buso \& Fatoki 2017; Pinkowski 2009; Tengeh 2013; Tengeh \& Nkem 2017) indicate that immigrant-owned businesses face various challenges in host business environments, 
namely hostility and lack of support. Regardless of these challenges, empirical studies have shown that immigrants adopt various practices in their businesses to assist them in establishing and operating businesses in their host communities (Fatoki \& Oni 2014; Khosa \& Kalitanyi 2014; Pinkowski 2009).

Several scholars (Fatoki \& Oni 2014; Khosa \& Kalitanyi 2014; Tengeh, Ballard \& Slabbert 2012; Toli \& Tengeh 2017) suggest that immigrant-owned small businesses create opportunities that have important implications for the South African economy. Moreover, in South Africa, immigrant-owned small retail businesses have increasingly been perceived as competitive and entrepreneurial relative to local businesses (Willemse 2013). It is suggested that the performance of immigrant-owned small businesses is attributed to the various practices that immigrant entrepreneurs adopt in obtaining information from various sources about opportunities in the business environment (Khosa \& Kalitanyi 2014; Toli \& Tengeh 2017). In this regard, immigrant entrepreneurs communicate and establish relationships with a wide array of individuals in the communities in which they operate that enable them to identify opportunities (Fatoki \& Oni 2014; Khosa \& Kalitanyi 2014).

\section{Problem statement}

Communicating with various social actors in the business environment allows immigrant entrepreneurs to share ideas, information and experiences. Communicating through mediums such as networks is critical for immigrant entrepreneurship because networks allow immigrants to gain access to local contacts who provide knowledge about the host society and the relevant business opportunities (Collins \& Low 2010; Nestorowicz 2011; Salaff, Greve \& Wong 2006). In a host country such as South Africa, there are numerous hostilities that immigrants face which makes the process of starting-up and operating an immigrantowned business challenging (Fatoki \& Oni 2014; Khosa \& Kalitanyi 2014). In this respect, immigrant entrepreneurs rely on various networks to facilitate the communication of various opportunities and resources in the environment (Fatoki \& Oni 2014).

In the South African context, most of the studies that have investigated the networking and communication practices of immigrant entrepreneurs have focused on African immigrant entrepreneurs, namely Somali, Zimbabwean, Congolese, Nigerian, Ghanaian and Ethiopian; little research has focused on Asian immigrant entrepreneurs such as the Chinese immigrant entrepreneurs. There has been a growing population of Chinese immigrant entrepreneurs settling in South Africa and starting up businesses. Increasingly, small businesses owned by Chinese immigrant entrepreneurs are being set up in South Africa drawing from the gradual influx of Chinese-made products in South Africa (Willemse 2013). It can be noted that these small businesses are entrepreneurial and competitive in the business environments in which they operate (Willemse 2013). However, little is known about the communication channels adopted by the Chinese immigrant entrepreneurs that facilitate their entrepreneurial endeavours, specifically the identification of opportunities in the South African business environment.

\section{Research objectives}

The main aim of the study was to obtain insight into the communication channels adopted by Chinese immigrant entrepreneurs to identify opportunities in the host community market.

To achieve the main aim of the study, the following objectives were formulated:

- To identify the nature of channels of communication used by the Chinese immigrant entrepreneurs to identify opportunities.

- To identify the stakeholders which the Chinese immigrant entrepreneurs communicated with to identify opportunities.

\section{Literature review}

\section{Immigrant entrepreneurs in perspective}

The term 'immigrant entrepreneur' can be used to describe an immigrant who engages in entrepreneurial activities in a host country, either through personal initiatives or through social networks (Tengeh et al. 2012). Immigrant entrepreneurs engage in entrepreneurial activities in a host country which include identifying opportunities, gathering resources, starting up and growing business ventures. Immigrants are either'pushed' or 'pulled' into entrepreneurship (Chrysostome 2010).

From a 'push' perspective, immigrants face many obstacles that prevent them from being assimilated into the formal job market of the host country; these obstacles include educational credentials, ethnic discrimination and language difficulties (Greve \& Salaff 2005; Piperopoulos 2010). The obstacles faced by the immigrants 'push' them and compel them to turn to self-employment, which acts as a creative and credible avenue within the host community.

It can also be noted that the obstacles that are faced by immigrants vary and are not limited to lack of educational credentials (Landau 2010) or a lack of language proficiency of the host country (Aldrich \& Waldinger 1990). For instance, Greve and Salaff (2005) observe that the credentials of a doctor from China are not recognised in Canada. Similarly, in South Africa, Landau (2010) notes that even those immigrants with employment rights and educational credentials face difficulties in being absorbed into the formal labour market. Piperopoulos (2010) contends that:

immigrants may encounter negative experiences within traditional organisational settings, and cultural barriers that block their advancement in mainstream economic markets. These challenges 'push' them out of organisations and channel them into entrepreneurship as an alternative route to economic prosperity. (p. 142) 
On the contrary, from a 'pull' perspective, immigrant entrepreneurs who have the knowledge of the specific needs and heritage of their co-ethnic consumers identify these opportunities and are drawn 'pulled' into entrepreneurship and self-employment by moving into a niche market (Piperopoulos 2010). Immigrants that are 'pulled' into entrepreneurship are individuals who leave their home country and freely decide to start a business to take advantage of a business opportunity in a host country. They value independence in starting up and operating their own business. In this respect, the main driving force influencing their migration is to identify opportunities in a host community (Chrysostome 2010).

In the same line of thinking, Baltar and Icart (2013) suggest that immigrant entrepreneurs who are pulled by opportunities start businesses to exploit a profitable business idea, regardless of there being possibilities of finding formal employment. These immigrant entrepreneurs are alert to new information and invest resources to start up their businesses. Consequently, failure in the mainstream markets to satisfy certain needs allows these immigrant entrepreneurs to offer innovations to meet unmet needs in specific sectors (Baltar \& Icart 2013; Chrysostome 2010). In this respect, the immigrant entrepreneurs actively seek opportunities within untapped markets in a host country with the intention of achieving business gains (Baltar \& Icart 2013).

In contrast, some immigrant entrepreneurs operate in the host country but still have networks with their home country and are able to source resources from those networks. They operate businesses that are embedded in the socio-economic context of the host country while also being embedded in the immigrant ethnic resources (such as ethnic networks). In this respect, from their networks with their home country, the immigrant entrepreneurs are able to identify opportunities in the host country which 'pull' them into entrepreneurial activity. The immigrant entrepreneurs exist in a dual economically embedded context (Chrysostome \& Lin 2010; Kloosterman \& Rath 2001). The ethnicity, historical and social contexts of the immigrants shape their business opportunities. Being embedded in specific networks of the home and host country allows the immigrants to identify opportunities in the host country and access resources from their home country that allow them to pursue these opportunities and offer innovative offerings to the market (Kloosterman, Van der Leeun \& Rath 1999).

Nieman and Nieuwenhuizen (2014) observe that networks support entrepreneurs by allowing them to have access to resources and opportunities. Networks allow immigrant entrepreneurs to gain access to local contacts and support to acquire sufficient knowledge about the host society and the relevant business opportunities (Collins \& Low 2010; Nestorowicz 2011; Salaff et al. 2006; Tengeh \& Lapah 2013). Social networks support the immigrant entrepreneurs by providing various ethnic resources in cases where immigrants perceive the host country as being hostile (Chrysostome 2010). A quantitative study conducted by Tengeh and Lapah
(2013) in South Africa explored the socio-economic trajectories of African immigrant entrepreneurs in Cape Town. It was noted that the African immigrant entrepreneurs were supported by their co-ethnic networks to establish and operate their businesses.

\section{Networks as communication channels}

Within an interactional context, social networks act as communication channels that provide social actors with an array of social and economic resources (Kwon \& Adler 2014; Santarelli \& Tran 2013; Smith-Doerr \& Powell 2005). In this respect, social actors gain information and insight from their social networks which vary in size and strength (Burt 2005; Davern 1997; Kwon \& Adler 2014). Kristiansen (2004) suggests that a change in the arrangement or type of actors within a social network will influence the relationships, and the resources transferred and exchanged. The variability of these structural configurations is presumed to result in different outcomes of both economic and social value. It is assumed that the larger an actor's network is with respect to contacts, the more benefits and resources the actor will gain. Kristiansen adds that relationships embedded in networks allow actors to be economic and social actors who have access to different types of information and opportunities.

Granovetter's (1973) seminal work concerning the strength of weak ties illustrates the power of networks in the transfer of contributions and information to actors for economic advancement. He suggests that weak ties diversify and diffuse information more efficiently than strong ties in an actor's network. Strong ties entail intimate connections which enhance and solidify group social cohesion, sense of belonging and identity, whereas weak ties entail less personal contacts which integrate a community of actors into the broader social system. Thus, Granovetter argues that weak ties are garnered from an array of circles and offer a diverse plethora of information in a more cost-effective manner than strong ties.

Kristiansen (2004) highlights the dynamic nature of networks as a key element of the quality of social networks. From the empirical work by Granovetter (1995), the work illustrates the evolving and dynamic nature of networks in positioning actors to access knowledge and ideas. Granovetter (1973, 1995) explains how actors starting small businesses, in the early stages of its existence, gather desired resources from their immediate family to identify opportunities. The familial relationships assist in providing support and guidance. These resources serve as a basis for identifying opportunities and the growth of the business over time as the business gets connected with more contacts in the broader community.

Burt $(1992,2005)$ suggests that inter- and intra-firm relations and communication in an economic context are influenced by the nature of the networks an actor possesses. Burt (1992, 2005) suggests that gaps between 'non-redundant contacts' or actors from different circles have access to different types of information and add inimitable value to one's network. 
These structural holes or gaps present worthy opportunities of entrepreneurial advantage to the actor who can bridge these separated streams or circles. In bridging these different groups, the individual has the control to fuse diverse ideas and propositions together, thereby enabling unprecedented creativity from which all parties will benefit.

Burt (1992) argues that individuals who have access to diverse networks and manage to actively bridge those networks are more likely to pursue more opportunities and advance in their endeavours. Essentially, networks provide actors with access, connecting them to circles and groups from which they are able to source valued opportunities and resources (Burt 1992, 2005).

In contrast, in the 'structural hole argument', Burt (1992) suggests that weaker network connections result in holes in the network, which allow the individuals within the networks to expand their reach to other groups, thereby increasing the flow of information between networks, while simultaneously increasing the 'control role' to the individual who is brokering the information. Thus, this benefit may create individualism within a network, thereby further weakening the networks in a group.

Immigrant entrepreneurs use different network channels as mediums of communication when searching for market-related information such as suppliers and business opportunities in the host community (Collins \& Low 2010; Nestorowicz 2011). Immigrant entrepreneurs use their communication channels embedded in networks to gain a deeper insight of the host business environment, pre and post establishing their businesses in the host environment (Saxenian 2000). Regardless of the challenges immigrant entrepreneurs face in host communities, immigrant entrepreneurs use various resources and networks as mediums of communication that assist them in establishing and operating businesses in their host countries (Fatoki \& Oni 2014; Khosa \& Kalitanyi 2014; Pinkowski 2009).

Similarly, Salaff et al. (2006) are of the view that immigrant entrepreneurs use different types of networks and ties to start up and operate their businesses. These ties include family, collegial, transnational and ethnic ties. Nee and Sanders (2001) support this view, adding that the family is a central source of support for immigrant entrepreneurs as they engage in entrepreneurial activities. Through their interaction and communication with various stakeholders, immigrant entrepreneurs are able to gain market information of the host environment (Chrysostome 2010; Collins \& Low 2010; Nestorowicz 2011).

Information obtained from various channels of communication, which include interactions with family members and friends, is key in rendering support to the establishment and operations of immigrant-owned businesses in a host environment (Collins \& Low 2010). Similarly, Salaff et al. (2006:4) contend that communication through ethnic ties provides contacts for immigrant entrepreneurs as they operate their businesses in a host country. Moreover, to overcome the challenge of operating businesses in a host country, some immigrant entrepreneurs draw on the different channels of communication they developed before migration to connect the new business to transnational networks (Saxenian 2000).

\section{Research mthodology}

A qualitative research design was followed in this study. Qualitative research seeks to explore human experiences, behaviour, motivations, perceptions and behaviour (Creswell 2009). Qualitative research is concerned with the collection and analysis of words, usually speech or writing. The design of qualitative research mainly includes the collection and analysis of words and actions with a view to gaining insight into people's differing perspectives and understandings (Bryman et al. 2014). Qualitative research allows the researcher to systematically capture a full, holistic, deeper and richer understanding of the phenomena. Qualitative studies are better suited to understanding individuals' interaction with their environment (Creswell 2009; Maxwell 2005; Strauss \& Corbin 1990).

\section{Sampling}

In this study, data were collected through semi-structured indepth interviews. Purposive sampling was adopted to select the research participants. Purposive sampling was initially adopted followed by snowball sampling. Purposive sampling involves the selection of suitable research participants who enable the research questions and goals to be realised (Babbie 2011). In this study, purposive sampling was adopted to ensure that the suitable research participants were selected, namely Chinese immigrant entrepreneurs. In contrast, snowball sampling involves initially selecting suitable research participants and thereafter asking those research participants to suggest other potential research participants who are suitable to answer the research questions (Babbie 2011). Data were collected from 21 immigrant entrepreneurs; 17 of the interviewees were males, while 4 of the interviewees were females. All the interviewees were older than 40 years with the exception of one interviewee who was 37 years old. The immigrant entrepreneurs selected in this study included Chinese born immigrant entrepreneurs who were operating small retail businesses in the Eastern Cape province of South Africa. All the interviewees had experience in operating a business and had been residing in South Africa for a period of more than 5 years and had migrated from China. All the interviewees had obtained their basic education in China and none of the interviews had higher level tertiary qualifications. The small retail businesses owned and operated by the interviewees employed between 6 and 20 employees. Additionally, these small retail businesses sold retail goods (such as food products, mobile airtime, appliances, cosmetics and clothing). The interviewees operated their small retail businesses in towns in the Eastern Cape province of South Africa, namely East London, Grahamstown, Port Elizabeth, King William's Town, Fort Beaufort and Uitenhage. 
The data collected from the semi-structured in-depth interviews were recorded and analysed using 'open coding' and 'constant comparison' techniques to generate emerging common themes. The process of 'open coding' involves breaking down, examining, comparing, conceptualising and categorising data (Strauss \& Corbin 1990). In contrast, 'constant comparison' involves the process of grouping data according to similarities and differences. To ensure quality in the data and the research process, attention was given to the principles of credibility, dependability, transferability, conformability and research ethics.

\section{Ethical considerations}

Ethical clearance was obtained from Rhodes University through the Management Department (reference: 2016Man16).

\section{The results}

In this study, various themes emerged relating to the communication channels adopted by immigrant entrepreneurs in the host community to identify opportunities. The themes of the communication channels adopted by the immigrant entrepreneurs included dependability of family, local employees as business connectors, gaining customer insight and interactions with competitors.

\section{Dependability of family}

Family members were mostly perceived as being a dependable source of information and resources for the small business. The immigrant entrepreneurs highlighted that by communicating with family members they were able to find opportunities related to which products to sell in the host communities. For the Chinese immigrant entrepreneurs, identifying and pursuing the opportunity to start up a small business in the South African business environment was enabled by trusting the advice, encouragement and support given by family members. Notably, several interviewees were supported and encouraged by their family members:

'After all, my brothers who I trust encouraged me to open business here and they were here to help me set up. They knew the area and what would sell here. With us, we tend to do things in families, so we all came up to South Africa one by one and we helped each other in starting up our businesses.' (Participant 5, male, owner)

'My relatives told me once I had enough money, I should open a supermarket, which is more profitable. So I opened a small supermarket in the township. I have had it until now, which is almost four years.' (Participant 7, male, owner)

'Generally, before we make decisions in the business we talk as a family. We look at whose solution is the best, and we stick to it. At the end of the day, the purpose of the business is profit for the family, so the best solution for the business will be adopted.' (Participant 3, male, owner)

Notably, family networks served as essential tools in identifying suitable business locations and identifying opportunities of what to sell. Moreover, several of the immigrant entrepreneurs elaborated how family members assisted them in identifying opportunities drawing from their prior experience and knowledge of operating a small business within the host community:

'In the beginning, I asked my brother to help me in the shop. He was here before me, and had been operating his store for some time. I asked him to help me set up the business.' (Participant 3, male, owner)

'We have numerous - four or five - shops, which are owned by various people in our family. One person who is my brother is responsible for buying stock for all the shops. He is based in Port Elizabeth, where most of the shops are, and he is very experienced.' (Participant 12, male, owner)

Additionally, family members would assist the immigrant entrepreneurs in identifying opportunities of accessing flexible suppliers. Therefore, for several immigrant entrepreneurs to establish relationships with suppliers, family members played a key role. Some of the interviewees elaborated how interactions with family members led to the family members introducing them to suppliers within the host community:

'My brother who is in the same business as me, advised me to open a shop here in Grahamstown. He introduced me to the wholesalers who trust him. They sell stock at cheaper prices. And they allow you to buy stock on credit. So you do not need to pay up front. So that is an advantage.' (Participant 5, male, owner)

'In the beginning family helped me in finding wholesalers. They also helped with funding for me to buy from the wholesalers.' (Participant 7, male, owner)

\section{Local employees as business connectors}

Local employees as business connectors involved local employees serving the function connecting and bridging the gap between the small business and the business opportunities in the local community. Information that would allow the small business to penetrate into the local market and access desirable opportunities was disseminated by the local employees to the immigrant entrepreneurs. Hence, market information from local employees conveyed to the immigrant entrepreneurs was useful for identifying, evaluating and accessing opportunities in the host community. Local employees enabled an iterative flow of business-related communication which would meaningfully link the small business to opportunities (such as sales opportunities) in the host community. Additionally, the role of acting as business connectors was enabled by the fact that local employees belonged to the local community and were able to speak the local language (isiXhosa) spoken in the host community. As a means of overcoming language barriers with local isiXhosa speaking customers, the immigrant entrepreneurs depended on their local isiXhosa speaking employees to initiate purposeful conversations with customers to gain an understanding of the needs of the community that could be best met by the small business.

For example, in a specific incident, the local employees enabled one immigrant entrepreneur to gain an understanding of the local food consumption habits of the community and 
thereby identify an opportunity to sell a specific type of sachets of soup to the community:

'We learn about the people's food here from our local [worker]. We do not know about them, so we rely on the [worker] to tell us what local food people like; for example, there was another time when my [worker] told me to sell satchels of this type of soup.... It is something that I have just started, so we will see if it goes well.' (Participant 15, female, owner)

Similarly, another immigrant entrepreneur described how his interaction with local employees enabled him to identify the opportunity of selling a specific type of local mince:

'Well, for example, I would not have thought of buying this [mince], if it were not for my staff. They told me to buy this for the shop.' (Participant 12, male, owner)

The immigrant entrepreneurs were aware that, based on their communication with local employees, they would be able to gain information regarding the product needs and opportunities in the community. In this respect, the immigrant entrepreneurs engaged in interactions with local employees to identify opportunities in the host environment.

\section{Gaining customer insight}

Gaining customer insight involved the practices adopted by the interviewees to identify opportunities through their communication and interactions with customers in the business environment. The practice by Chinese immigrant entrepreneurs of communicating and engaging with the different customers who entered the small business and gauging the appropriate interactional practices to engage with these customers to identify opportunities for the small business was manifested through the theme of 'gaining customer insight'.

Communicating with customers who were approachable and interactive regularly led to the attainment of deep knowledge regarding market needs and the nature of opportunities. In this respect, the immigrant entrepreneurs would observe customers and make a situational judgement on whether to engage with a customer to gain an understanding of opportunities in the host community. The immigrant entrepreneurs approached several customers to validate opportunities and gain multiple perspectives of opportunities in the host community. The triangulation of insights from varying customers (old, young, males, females, new customers, repeat customers) yielded deep knowledge of opportunities.

Nonetheless, the Chinese immigrant entrepreneurs highlighted that they gained deep knowledge from their repeat customers who were noted as being more friendly and approachable. In this respect, through engaging in interactions with repeat customers the immigrant entrepreneurs managed to identify several opportunities in the host community. This is highlighted in the following quotation from one of the immigrant entrepreneurs:
'When I get some ideas about certain products from workers or just from talking with friends and family, I would also ask the regular customers if a certain product is something that they would buy. ... Occasionally, the regular customers do come with some suggestions and ideas which we do consider.' (Participant 17 , male, owner)

One of the immigrant entrepreneurs recalled an incident in which engaging in interactions with frequent and approachable customers enabled the identification and validation of an opportunity to sell a particular product (called 'Refresh') in the market:

'Even if you have money, you cannot open a shop. You do not know the basics of operation yet. For example, operating a business in PE is very different from operating a business in Johannesburg. A product that will sell well there will not necessarily sell well here. You must look at your local area and get to know it. So take the cool drink example again. Twizza does not sell well in Grahamstown. It appeals more to certain people. So here, Refresh would sell more. So it is important to understand the taste in your town. And that also comes from communicating with your frequent customers. So you would ask, "Why do you prefer this drink over another?" So communication is very important. And when you are given an idea you need to keep asking other customers to get their opinion of the idea.' (Participant 6, male, owner)

From this quotation, it can be noted that the interactions and engagement with customers in a consultative manner led to the identification of opportunities in the host community. Commonly, interactions with customers were associated with the immigrant entrepreneurs being physically present at the business premises and engaging with the customers to try to influence their purchase decisions as well as gain as much insight as possible of opportunities to serve their needs better. A co-identification of needs with customers was vital in the process of identifying sales opportunities for the small business. For example, one immigrant entrepreneur described how he engaged in interactions with customers and also listened to their requests at the small business. In this respect, he managed to identify the opportunity to sell a specific product ('Nik Naks') by interacting, engaging and listening to several customers who requested the product:

'We talk to customers and listen to how often a particular product is requested by the customers, and decide whether to sell it or not. ... Like with a product like Nik Naks, a lot of people asked for it, but I did not know what it is. Eventually I asked a local customer about it, and he told me. So I stocked up and they are now selling well.' (Participant 11, male, owner)

In conclusion, gaining customer insight through interactions with customers emerged as a key channel of communication for the Chinese immigrant entrepreneurs to identify opportunities in the host environment.

\section{Interaction with competitors}

Mindful of the presence of other foreign business competitors in the business environment, immigrant entrepreneurs cooperated with competitors to establish 
mutually beneficial relationships. These relationships and channels of communication were perceived as a useful asset to source information for the business and identify opportunities. Maintaining close contact and dialogue with competitors cemented relationships to promote and support the business which represented channels of communication that enabled the dynamic flow of ideas and information about the market. Relationships with foreign business competitors enhanced the exchange of knowledge and an understanding of unmet customer needs:

'The other foreign owned businesses can also be helpful. I speak to their owners sometimes and they can give me good advice on things like what their customers are buying.' (Participant 14, male, owner)

Another immigrant entrepreneur elaborated on the need for business relations through making friends in business who can provide advice regarding possible business opportunities:

'I learned that in business, relationships are important. You cannot avoid people. And from your connections, you can receive information. This might make the things that you are doing easier. So this requires different friends such as other businesses, who can give you different sources of information. For example, they can tell what business opportunities are there. Sometimes they cannot exploit these opportunities themselves, so you can exploit them.

Occasionally we would hear from other store-owners in this area about products which are needed here.' (Participant 12, male, owner)

In this regard, interaction with other competing businesses was a communication channel used by the immigrant entrepreneurs to identify the opportunities in the business environment.

\section{Discussion}

The networks and relationships established by the Chinese immigrant entrepreneurs presented the channels of communication that facilitated the identification of opportunities. In the channels of communication the Chinese immigrant entrepreneurs adopted to identify opportunities, they interacted with several stakeholders, namely family members, local employees, customers and competitors. In this respect, the Chinese immigrant entrepreneurs created and maintained networks and relationships with family members, local employees, customers and competitors. Immigrant entrepreneurs would communicate with family members to gain insight of opportunities of products to sell in the host environment. Furthermore, family members introduced them to suppliers in the host environment and guided them in configuring their product offerings. This finding is in support of the assertions by several scholars (namely Collins \& Low 2010; Nee \& Sanders 2001; Salaff et al. 2006; Tengeh \& Lapah 2013; Tengeh \& Nkem 2017; Wang \& Warn 2018) who suggest that immigrant entrepreneurs use family members and their ethnic ties to obtain resources to start up their businesses and identify opportunities. Family members provide assistance in identifying and pursuing opportunities in the environment (Nee \& Sanders 2001; Tengeh \& Nkem 2017). In this respect, the networks with different social ties enable the start-up and operations of their businesses (Chrysostome 2010; Salaff et al. 2006).

In contrast, local employees served the function of bridging the gap between the immigrant entrepreneurs and the business opportunities in the local community. Local employees disseminated information about desirable products sought by the community and opportunities in the market. From their interactions with local employees, the immigrant entrepreneurs were able to gain a deep understanding of local tastes and which products were desired by the community. Immigrant entrepreneurs employ local employees who are key in the operations of their businesses (Fatoki \& Patswawairi 2012.

Establishing relationships with customers played a pivotal part in allowing market information to flow to the immigrant entrepreneurs. From their interactions with customers, the immigrant entrepreneurs were able to identify opportunities and gain insight of the product-related unmet needs of the market. The immigrant entrepreneurs established good relationships with the customers and this enabled them to ask them questions about products that they thought would sell in the community. Establishing long-term relationships with customers is an essential marketing strategy used by foreign-owned businesses to ensure that they identify and meet the unmet needs of consumers (Jamal 2005).

In contrast, the immigrant entrepreneurs interacted with competitors in the business environment and established mutually beneficial relationships with these competitors. Interacting with competitors allowed the dynamic flow of ideas and information about the market between the immigrant entrepreneurs and their competitor. In this respect, communication with competitors allowed the immigrant entrepreneurs to identify opportunities in the market. Immigrant-owned businesses established ties with other businesses to facilitate the performance of their businesses in host environments (Saxenian 2000).

\section{Managerial implications}

The findings contribute to the understanding of communication channels adopted by immigrant entrepreneurs to identify opportunities. The research highlights the centrality of establishing and maintaining relationships with various stakeholders in the business environment to enable the identification of opportunities. Furthermore, relationships with different stakeholders (namely customers, local employees, family and competitors) enable an iterative flow of information between the business owners and different stakeholders in the business environment. For example, long-term relationships with customers enable the business owners to gain a deeper insight of the needs of customers. It is key for business owners to devote time to interact with the customers and be physically present at the business premises to always monitor and observe the activities at the premises. 
Business owners can gain customer insight by communicating directly with the customers.

In contrast, business owners can draw from the insight of their employees to identify opportunities. Immigrant entrepreneurs are noted to leverage from their local employees. Incentivising local employees can enable the local employees to communicate to the host community the offerings of the business and vice versa. In addition, interacting with competitors in the business environment through collaborations with competitors can enable the sharing of ideas and the identification of opportunities.

Additionally, immigrant entrepreneurs need to develop strategic marketing plans to ensure that they effectively communicate with their stakeholders and establish longterm relationships with their stakeholders in the business environment. From a strategic marketing perspective, systematically developing mechanisms to obtain information from the market that ensures the long-term success of the business is key.

\section{Limitations and recommendations for future research}

The use of one method of data collection was acknowledged as a limitation of this study. Interviews were the source of data in this study. The use of focus group discussions could have enabled the researcher to gain a deeper insight of the communication channels adopted by the immigrant entrepreneurs.

Another limitation of this study was the use of only immigrant entrepreneurs who were Chinese in origin and operated their businesses in the Eastern Cape province of South Africa. Multiple groups of immigrant entrepreneurs from different countries could have been used in the study to gain deeper and broader insight from the multiple perspectives. Additionally, the use of only the immigrant entrepreneurs was a limitation in the study because the organisational members could have provided a broader perspective of the communication channels adopted by immigrant-owned businesses to identify opportunities.

Future research could also broaden the nature of research participants by conducting interviews with customers, family members and local employees. Furthermore, future research could be in the form of a longitudinal study which could examine the communication channels adopted by immigrant entrepreneurs over an extended period of time. Future studies can seek to investigate how immigrant entrepreneurs coordinate communication channels to gain insight of the market and inform, create awareness and persuade local customers to engage in purchase behaviour.

\section{Conclusion}

The research aimed to investigate the communication channels used by Chinese immigrant entrepreneurs to identify opportunities in the host business environment.
A qualitative research design was adopted to explore the various perspectives of the participants. Data were collected through semi-structured interview questions; data were analysed through constant comparison techniques. The results indicated that the immigrant entrepreneurs used a variety of communication channels to identify opportunities in the market. The immigrant entrepreneurs established various networks with stakeholders that presented the communication channels used to identify opportunities in the business environment. They drew from their networks and relationships with family members, local employees, customers and competitors. The communication channels which the immigrant entrepreneurs adopted enabled an iterative flow of information related to the market.

From the results of this study, local South African entrepreneurs and business owners can learn from the networking activities adopted by the Chinese immigrant entrepreneurs in South Africa to enhance the performance of their businesses. Local entrepreneurs and business owners can focus on relationship-building practices directed at their customers, employees and competitors. In this respect, local entrepreneurs need to invest time and resources in building long-term relationships with different stakeholders, namely customers, customers, local employees and competitors.

\section{Acknowledgements}

The authors would like to thank the National Research Foundation of South Africa for providing funding for this study (Grant No. 93636). The views contained in this article are the authors' own and not an official position of the institution or the funder.

\section{Competing interests}

The authors declare that they have no financial or personal relationships that may have inappropriately influenced them in writing this article.

\section{Authors' contributions}

T.R.N. collected data for this study. L.L. and M.K. assisted T.R.N. in analysing and discussing the results.

\section{References}

Aldrich, H. \& Waldinger, R., 1990, 'Ethnicity and entrepreneurship', Annual Review of Sociology 16, 111-35.Babbie, E., 2011, Introduction to social research, 5th edn., Wadsworth, Cengage Learning, Belmont, CA

Baltar, F. \& Icart, I.B., 2013, 'Entrepreneurial gain, cultural similarity and transnational entrepreneurship', Global Networks 13(2), 200-219. https://doi.org/10.1111/ glob.12020

Bryman, A., Bell, E., Hirschsohn, P., Dos Santos, A., Du Toit, J., Masenge, A. et al., 2014 Research methodology: Business and management contexts, Oxford Press, Cape Town.

Burt, R.S., 1992, Structural holes: The social structure of competition, Harvard University Press, Cambridge, MA.

Burt, R.S., 2005, Brokerage and closure, Oxford University Press, London.

Chrysostome, E., 2010, 'The success factors of necessity immigrant entrepreneurs: In search of a model', Thunderbird International Business Review 52(2), 137-152. https://doi.org/10.1002/tie.20320

Chrysostome, E. \& Lin, X., 2010, 'Immigrant entrepreneurship: Scrutinising a promising type of business venture', Thunderbird International Business Review 52(2), 77-82. https://doi.org/10.1002/tie.20315 
Collins, J. \& Low, A., 2010, 'Asia female immigrant entrepreneurs in small and mediumsized businesses in Australia', Entrepreneurship \& Regional Development 22(1) sized businesses in Australia', Entrepreneurship \& Reg
97-111. https://doi.org/10.1080/08985620903220553

Creswell, J.W., 2009, Research design: Qualitative, quantitative, and mixed methods approaches, 3rd edn., Sage, Thousand Oaks, CA.

Davern, M., 1997, 'Social networks and economic sociology: A proposed research agenda for a more complete social science', American Journal of Economics and Sociology 56(3), 287-302. https://doi.org/10.1111/j.1536-7150.1997.tb03359.x

Fatoki, O. \& Oni, O., 2014, 'The networking behaviour of immigrant entrepreneurs in South Africa', Mediterranean Journal of Social Sciences 5(20), 284-290. https:// doi.org/10.5901/mjss.2014.v5n20p284

Fatoki, O. \& Patswawairi, T., 2012, 'The motivations and obstacles to immigrant entrepreneurship in South Africa' Journal of Social Science 32(2), 133-142.

Granovetter, M., 1973, 'The strength of weak ties: A network theory revisited', Sociological Theory 1, 201-233. https://doi.org/10.2307/202051

Granovetter, M., 1995, Getting a job: A study of contacts and careers, 2nd edn., University of Chicago Press, Chicago, IL.

Greve, A. \& Salaff, J., 2005, 'Social network approach to understand the ethnic economy: A theoretical discourse', Geoforum 62(1), 7-16. https://doi. org/10.1007/s10708-005-3919-0

Halkias, D., Abadir, S., Akrivos, D., Harkiolakis, N., Thurman, P. \& Caracatsanis, S., 2007 Characteristics and business profile of immigrant-owned small firms: The case of Albanian immigrant entrepreneurs in Greece, Hellenic American University, Manchester, Paper 155, pp. 1-29.

Jamal, A., 2005, 'Playing to win: An explorative study of marketing strategies of small ethnic retail entrepreneurs in the UK', Journal of Retailing and Consumer Services 12(2005), 1-13.

Khosa, R.M. \& Kalitanyi, V., 2014, 'Challenges in operating micro-enterprises by African foreign entrepreneurs in Cape Town, South Africa', Mediterranean Journal of Social Sciences 5(10), 205-215. https://doi.org/10.5901/mjss.2014.v5n10p205

Kloosterman, R. \& Rath, J., 2001, 'Immigrant entrepreneurs in advanced economies: Mixed embeddedness further explored', Journal of Ethnic and Migration Studies 27(2), 189-202.

Kloosterman, R., Van Der Leeun, J. \& Rath, J., 1999, 'Mixed Embeddedness: (In) formal economic activities and immigrant businesses in the Netherlands', Internationa Journal of Urban and Regional Research 23(2), 253-267. https://doi.org/10.1111/ 1468-2427.00194

Kristiansen, S., 2004, 'Social networks and business success: The role of subcultures in an African Context', American Journal of Economics and Sociology 63(5), 1149-1171. https://doi.org/10.1111/j.1536-7150.2004.00339.x

Kwon, S.-E. \& Adler, P.S., 2014, 'Social capital: Maturation of a field of research', Academy of Management Review 39(4), 412-422. https://doi.org/10.5465/amr.2014.0210

Landau, L.B., 2010, 'Discrimination and development? Urbanisation and sustainable livelihoods in Johannesburg', in J.Crush \& B. Frayne (eds.), Surviving on the move: Migration, poverty and development in Southern Africa, IDASA, Cape Town.

Masocha, R., Buso, B. \& Fatoki, O., 2017, 'Competitive marketing by immigrant SMMEs in South Africa', Journal of Social Sciences 50(1), 14-132. https://doi.org/10.1080 /09718923.2017.1311727

Maxwell, J.A., 2005, Qualitative research design: An interactive approach, 2nd edn., Sage, Thousand Oaks, CA.

Nee, V. \& Sanders, J., 2001, 'Understanding the diversity of immigrant incorporation: A forms-of-capital model', Ethnic and Racial Studies 24(3), 386-411. https://doi. org $/ 10.1080 / 01419870020036710$
Nestorowicz, J., 2011, 'Known knowns and known unknowns of immigrant selfemployment', Centre of Migration Research 45(103), 3-66.

Nieman, G.H. \& Nieuwenhuizen, C., 2014, Entrepreneurship: A South African perspective, 3rd edn., Van Schaik, Pretoria.

Pinkowski, J., 2009, Challenges and promises for immigrant entrepreneurship in Dublin, Dublin City Council Economic Development Unit, Dublin, pp. 1-63.

Piperopoulos, P., 2010, 'Ethnic minority businesses and immigrant entrepreneurship in Greece', Journal of Small Business and Enterprise Development 17(1), 139-158. https://doi.org/10.1108/14626001011019170

Sahin, M., Nijikam, P. \& Baycan-Levent, T., 2006, Migrant entrprenuership from the perspective of cultural diversity, Series Research Memorada, No. 6, VU, Amsterdam.

Salaff, J., Greve, A. \& Wong, S., 2006, Business social networks and immigrant entrepreneurs from China, Chinese Ethnic Economy: Global and Local Perspectives, Routledge, London.

Santarelli, E. \& Tran, H.T. 2013 'The interplay of human and social capital in shaping entrepreneurial performance: The case of Vietnam' Small Business Entrepreneurship 40, 435-458. https://doi.org/10.1007/s11187-012-9427-y

Saxenian, A., 2000, Silicon Valley's new immigrant entrepreneurs, Centre for Comparative Immigration Studies, Working Paper. 15, Centre for Comparative Immigration Studies, San Diego, CA.

Smith-Doerr, L. \& Powell, W., 2005, 'Networks and economic life', in N.J. Smelser \& R. Swedberg (eds.), The handbook of economic sociology, pp. 379-403, Princeton University Press, Princeton, NJ.

Strauss, A. \& Corbin, J., 1990, Basics of qualitative research: Grounded theory procedures and techniques, Sage Publications, London.

Tengeh, R.K., 2013, 'Advancing the case for the support and promotion of African immigrant owned businesses in South Africa', Mediterranean Journal of Socia Sciences 4(2), 347-359. https://doi.org/10.5901/mjss.2013.v4n2p347

Tengeh, R.K. \& Lapah, C.Y., 2013, 'The Socio-Economic Trajectories of Migrant Street Vendors in Urban South Africa', Mediterranean Journal of Social Sciences 4(2), 109-127.

Tengeh, R.K., Ballard, H.B. \& Slabbert, A.S., 2012, 'Do immigrant-owned business grow financially? An empirical study of African immigrant-owned businesses in South Africa. A framework for acquiring the resources vital for the start-up of a business in South Africa: An African immigrant's perspective', European Journal of Socia Sciences 23(3), 362-381.

Tengeh, R.K. \& Nkem, L., 2017, 'The role of stokvels in financing immigrant-owned businesses in South Africa', International Business Management 11(8-10), 1993-5250.

Toli, L. \& Tengeh, R.K., 2017, 'Sources of entrepreneurial opportunities explored by African immigrant entrepreneurs in South Africa', Academy of Entrepreneurship Journal 23(2), 1528-2686.

Wadhwa, V., Saxenian, A., Rissing, B. \& Gereffi, G., 2007, America's new immigrant entrepreneurs, Master of Engineering Management Program, Duke University, School of Information, U.C., Berkeley, pp. 1-41.

Wang, Y. \& Warn, J., 2018, 'Chinese immigrant entrepreneurship: Embeddedness and the interaction of resources with the wider social and economic context', International Small Business Journal: Researching Entrepreneurship 36(2) 131-148. https://doi.org/10.1177/0266242617726364

Willemse, L., 2013, 'The role of economic factors and guanxi networks in the success of Chinese shops in Johannesburg, South Africa', Urban Forum 25, 1, 105-123. 